\title{
SEGREGASI SOSIAL PASCA PEMILU 2019 DAN PENTINGNYA PENDIDIKAN MULTIKULTURAL ISLAMI
}

\section{PIRMAN NURSYAMSI}

\begin{abstract}
This study aims to systematically describe the post-2019 general election social segregation in the SMK Bakti Karya Parigi community. The method used is descriptive qualitative method. The results of the study show that post-2019 social segregation in the community of SMK Bakti Karya Parigi both in the school environment and in the dormitory environment has never happened, because all students, teachers, and the surrounding community tend to be familiar with differences of opinion in what terms even. They are accustomed to diversity and differences, so that they do not care about the heat of the country's democratic space that occurred after the 2019 election. They continue to work together in an effort to give their voting rights in the 2019 election. SMK Bakti Karya Parigi as one of the pioneers of multicultural education in Indonesia has provided a good example. both for the community to be able to respect each other and respect the differences so that later the community will not be easily provoked and manipulated by people who want to divide the unity and integrity of the people. Multicultural education for the community is very important because from the multicultural education the community will be able to understand differences, both in terms of religion, social, and culture.
\end{abstract}

Keywords: Social segregation, public elections, multicultural education

\section{Pendahuluan}

Pelaksanaan pemilihan umum (Pemilu) menjadi indikator dalam sistem demokrasi karena rakyat dapat berpartisipasi dalam menentukan pilihan politiknya terhadap pemerintahan dan negaranya. Melalui pemilu rakyat bisa memilih para wakilnya untuk duduk dalam parlemen maupun struktur pemerintahan. Dalam sejarah perjalanan bangsa Indonesia pemilu menjadi upaya nyata dalam mewujudkan tegaknya demokrasi dan merealisasikan kedaulatan rakyat dengan prinsip jujur dan adil (jurdil) serta langsung, umum, bebas dan rahasia (luber). Pemilu juga menjadi sarana lima tahunan pergantian kekuasaan dan kepemimpinan nasional, dimana partai politik dapat saling berkompetisi untuk mendapatkan simpati rakyat dalam memperoleh kekuasaan politik (legislatif, eksekutif) yang legitimasinya sah secara undang-undang dan konstitusional. 
Sebagai pemegang kedaulatan, maka rakyat yang menentukan corak dan cara serta tujuan apa yang hendak dicapai dalam kehidupan kenegaraan. Hal ini menunjukkan bahwa rakyat berkuasa secara independen atas dirinya sendiri (Nurtjahjo, 2006 : 32). Selain itu, pentingnya pemilu dalam negara demokrasi sesuai dengan tujuan penyelenggaraan pemilihan umum itu sendiri, yaitu membuka peluang untuk terjadinya pergantian pemerintahan sekaligus momentum untuk menguji dan mengevaluasi kualitas dan kuantitas dukungan rakyat terhadap keberhasilan dan kekurangan pemerintah yang sedang berkuasa (Bisariyadi, et.al., 2012 : 533).

Pemilu sering disebut sebagai ajang pesta demokrasi rakyat yang menjadi cerminan ikut andilnya rakyat dalam menentukan pemimpin dan arah perkembangan bangsa. Namun dalam perkembangannya pemilu di Indonesia masih banyak kekurangan dan menjadi pekerjaan rumah yang perlu diperbaiki bersama oleh seluruh elemen bangsa. Perubahan model sistem pemilu dari pemilu ke pemilu berikutnya tentu menjadi hal yang dibutuhkan, hal ini dikarenakan perkembangan dan situasi perpolitikan bangsa Indonesia yang terus berubah. Masih banyak sebagian masyarakat yang menilai bahwa selama ini pemilu hanya sebagai agenda rutinitas lima tahunan yang menghabiskan uang rakyat, sementara hasil dari pelaksanaan pemilu itu sendiri belum mampu menciptakan masyarakat yang adil dan sejahtera. Anggapan seperti ini tentunya menjadi masukan bagi penyelenggara pemilu untuk lebih baik dalam melaksanakan agenda pemilu di masa yang akan datang.

Adanya keputusan pemilu serentak 2019 tentu menjadi tantangan dan peluang bagi seluruh elemen bangsa dalam perbaikan sistem politik dan demokrasi di Indonesia. Agar pemilu serentak 2019 dapat terlaksana dengan baik diperlukan kesungguhan dari pemerintah dan anggota parlemen untuk tidak terjebak dalam permainan politik yang oportunis dan pragmatis, penyelenggaraan pemilu serentak 2019 harus menjadi referensi sistem pemilu baru di Indonesia.

Selanjutnya masyarakat sebagai manusia merupakan mahkluk sosial yang harus hidup secara bersama, hal ini merupakan naluri alami untuk membentuk sebuah kelompok didalam lingkungan, dimana ada suatu lingkungan yang berbeda dalam masyarakat, tentunya akan membentuk aktivitas yang berbeda-beda untuk setiap masyarakat. Aktivitas yang terstruktur dan menjadi kebiasaan yang diulangulang dalam masyarakat ini merupakan budaya dan cerminan masyarakat itu sendiri hingga akhirnya akan membentuk pola - pola yang berbeda dalam kehidupan serta berperan besar dalam membentuk lingkungan sosial, karakter masyarakat, integrasi, interaksi sosial dan kontruksi sosial masyarakat dalam melakukan tindakan sosial.

Berkaitan dengan pemilu serentak 2019 masyakat sebagai mahluk sosial harus dapat lebih mengerti dan memahami sistem pemilu serentak 2019, agar 
tidak terjadinya kecurangan dan penyimpangan dalam pelaksanaan pemilu serentak 2019 tersebut, tanpa meilhat latar belakang masyarakat baik dari segi suku bangsa, etnis, agama, dan sosial budaya. Dalam hal ini masyarakat Indonesia harus dapat mengedepankan toleransi untuk mencapai suatu kerukunan dalam upaya suksesi kegiatan pemilu serentak 2019. Toleransi tersebut tidak akan mudah tercapai tanpa adanya peran penting dari pendidikan. Pendidikan yang tepat dalam hal ini adalah pendidikan multikultural. Multikultural di satu pihak merupakan suatu paham dan di pihak lain merupakan suatu pendekatan yang menawarkan paradigma kebudayaan untuk mengerti perbedaan-perbedaan yang selama ini ada di tengah-tengah masyarakat kita dan dunia. Perbedaan bila tidak dikelola dengan baik maka akan menimbulkan konflik, yang bahkan bahkan akhirakhir ini menjadi kenyataan. Lebih lanjut pendidikan multikultural adalah sebuah pendekatan pada pengajaran dan pembelajaran yang didasarkan atas menilai dan kepercayaan demokratis dan melihat melihat keragaman sosial dan interpendensi dunia sebagai bagian dari pluralitas budaya.

Namun dalam kehidupan sosial tidak akan terlepas dari suatu permasalahan dalam konteks perbedaan pendapat. Perbedaan pendapat tersebut hendaknya tidak menimbulkan suatu pemisah antar masyarakat, yang pada akhirnya akan mengakibatkan dampak yang sangat besar dalam khususnya pelaksanaan pemilu serentak 2019. Pemisahan tersbeut biasa disebut dengan segresi. Segregasi dalam Kamus Besar Bahasa Indonesia (KBBI) merupakan pemisahan (dari satu golongan ke golongan lainnya). Secara sosiologis, segregasi sosial (social segregation) merupakan kecenderungan orang untuk lebih senang berinteraksi dengan orang lain yang sama secara etnik (Blumenstock \& Fratamico, 2013). Orang yang berada di luar etniknya dianggap sebagai out group (di luar kelompoknya).

Insiden di area Car Free Day (CFD) di Jakarta antara sekelompok orang berkaos dengan tulisan \#2019 Ganti Presiden dengan seorang ibu berkaos \#Dia Sibuk Kerja sebelum pelaksanaan pemilu serentak 2019 menunjukkan adanya segregasi sosial di masyarakat. Pemicunya karena perbedaan simbol dan tulisan di kaos. Tulisan di kaos bisa menjadi indikasi ke mana arah aspirasi politik terkait pemilihan presiden 2019. Kelompok \#2019 Ganti Presiden mewakili oposisi yang menginginkan pilpres 2019 melahirkan presiden baru. Kaos \#Dia Sibuk Bekerja bisa dimaknai sebagai kelompok pro Presiden Joko Widodo melanjutkan periode kedua.

Tulisan di kaos yang menjadi ramai tersebut memang bukan soal etnisitas, melainkan perbedaan pandangan politik terkait sosok presiden mendatang. Meskipun bisa saja hal tersebut ditarik ke wilayah perbedaan etnis. Namun dalam politik semua bias terjadi dan dampak yang diakibatkan sama. Sebagai negara demokrasi, kompetisi kelompok yang mewakili kontestan pilpres sebenarnya keniscayaan. Dan yang patut mendapatkan 
perhatian justru pada tafsir-tafsir atas keterbelahan dan perbedaan yang semakin menonjol.

Kepentingannya sebagai politisi lebih terlihat. Para aktivis partai politik sebenarnya mengemban misi untuk melakukan pendidikan politik kepada rakyat, sebagai implementasi fungsi partai politik. Politisi berkewajiban memberikan pencerahan kepada publik, terlebih saat terjadi insiden yang berpotensi membahayakan integrasi bangsa. Hasrat sangat besar untuk berkuasa tak perlu mengalahkan akal sehat, apalagi mendekonstruksi nilai-nilai demokrasi.

Demokrasi bukan sekadar mekanisme politik. Dari sisi prosedur, tidak ada yang memungkiri proses politik di Indonesia cukup mewakili sebagai negara demokrasi. Pemilu bebas tanpa intervensi negara. Kebebasan berpendapat di ruang publik sangat terjamin. Apabila ingin mengkritik pemerintah tidak ada yang melarang selama dilakukan secara elegan. Tapi demokrasi ternyata tak sekadar prosedur. Kualitas demokrasi memerlukan kedewasaan semua pihak, termasuk kecerdasan warga dalam berinteraksi di ruang publik saat mengemukakan pandangan politiknya. Kualitas, bobot, wacana yang dikembangkan menjadi indikasi penting tentang kualitas demokrasi di Indonesia.

\section{Metode Penelitian}

Dalam penelitian ini, peneliti menggunakan pendekatan kualitatif dan berbetuk deskriptif. Dikarenakan dalam penelitian ini peneliti berusaha memaparkan realitas yang ada tanpa memerlukan data yang berupa angkaangka (kuantitatif) dan berusaha menggambarkan suatu keadaan beserta segala aspeknya.

Dengan kata lain penelitian ini menuturkan dan menafsirkan data yang ada, misalnya tentang situasi yang alami, satu hubungan, kegitan, pandangan, sikap yang nampak atau tentang suatu proses yang sedang berlangsung, pengaruh yang sedang bekerja, kelainan yang sedang muncul, kecenderungan yang menampak, pertentangan yang meruncing dan sebagainya.

Metode penelitian yang digunakan dalam penelitian ini adalah menggunakan metode penelitian kualitatif. Metode penelitian kualitatif sering disebut metode penelitian naturalistik karena penelitiannya dilakukan dalam kondisi yang alamiah, penelitian kualitatif bermanfaat untuk memberikan gambaran umum tentang latar penelitian dan sebagai bahan pembahasan hasil penelitian (Sugiyono, 2008 : 14).

Penelitian ini merupakan penelitian lapangan (Feal Raeseach) yaitu dilakukan untuk memahami fenomena sosial dari pandangan pelakunya. Data yang di peroleh peneliti langsung berasal dari lapangan yaitu lokasi penelitian, SMK Bakti Karya Parigi. Peneliti menggunakan metode pengumpulan data yaitu observasi sebelumnya mengenai keadaan lingkungan sekolah SMK Bakti Karya Parigi, wawancara kepada pihak-pihak yang berkompeten diantaranya 
kepala sekolah, guru, karyawan dan siswa. Peneliti sendiri terjun langsung kelapangan yaitu di SMK Bakti Karya Parigi.

Berdasarkan keterangan tersebut, penelitian ini merupakan penelitian kualitatif yang bersifat deksriptif, Sehingga peneliti mengungkapkan atau memaparkan secara detail tentang "Segregasi Sosial Pasca Pemilu 2019 dan Pentingnya Pendidikan Multikultural".

Data adalah suatu informasi yang dikatakan oleh manusia yang menjadi subjek penelitian, hasil observasi, fakta, dokumen yang sesuai dengan focus penelitian. Informasi dari subjek penelitian dapat diperoleh secara verbal melalui wawancara atau dalam bentuk tertulis melalui analisa dokumen. (Ahmadi, 2005 : 63). Data merupakan keterangan-keterangan tentang suatu hal, dapat berupa sesuatu yang diketahui atau yang dianggap atau anggapan, atau suatu fakta yang digambarkan lewat angka, simbol, kode dan lain-lain. (Hasan, 2004 : 19). Data yang dikumpulkan dalam penelitian kualitatif meliputi data pengamatan, wawancara dan dokumentasi. (Ahmadi, 2005 : 63).

Data dalam penelitian ini adalah keterangan, tindakan, kegiatan, perilaku dan catatan yang dapat dijadikan bahan dasar kajian berkenaan dengan Segregasi Sosial Pasca Pemilu 2019 dan Pentingnya Pendidikan Multikultural. Sumber data adalah subyek dimana data diperoleh. (Arikunto, 2006 : 79). Atau subyek yang dapat memberikan data berupa kata-kata, tindakan maupun dokumen-dokumen terkait dengan penelitian yang dilakukan. Maka sumber data dalam penelitian ini adalah kepala sekolah, guru-guru, staf Tu dan masyarakat umum lingkungan sekolah dan asrama.

Prosedur pengumpulan data yang diperoleh dalam penelitian ini melalui beberapa cara studi lapangan. "Studi lapangan adalah teknik atau metode penelitian dimana peneliti langsung terjun ke lapangan untuk memperoleh data-data primer yang dibutuhkan" (Arikunto, 1985 : 130). Teknik atau metode pengumpulan datanya adalah metode observasi, metode wawancara dan dokumentasi. Dalam penelitian kualitatif kita mengenal dengan credibility, transferability, dependability dan confirmability. Istilah tersebut pada dasarnya merupakan criteria yang bertujuan untuk menjamin trustworthiness (kelayakan untuk dipercaya) sebuah penelitian. Istilah tersebut diatas merupakan rangkuman dari tahap pengecekan keabsahan data yang merupakan bagian yang sangat penting dari penelitian kualitatif. (Meleong, 2007 : 324). Pemeriksaan keabsahan data didasarkan atas kriteria tertentu. Kriteria itu terdiri atas derajat kepercayaan (kredibilitas), keteralihan, kebergantungan, dan kepastian.

Terdapat dua tahap dalam analisis data, sebagaimana yang dekemukakan oleh (Sugiyono, 2005 : 335) pada analisis data ada 2 tahap yang dilakukan oleh peneliti pada pendekatan kualitatif yaitu : 1) Analisis data selama dilapangan, segala sesuatu yang ditemukan dilapangan berkaitan dengan penelitian. 2) Analisis setelah data terkumpul. Analisis data ini berbicara tentang bagaimana mencari serta mengatur secara sistematis data, 
transkrip yang sudah diperoleh dari wawancara dan dokumentasi, maka peneliti pada penelitian ini menganalisa data-data hasil wawancara dan dokumentasi obyek penelitian serta menganalisa data yang sudah terkumpul. (Sugiyono, 2005 : 335).

\section{Hasil Penelitian dan Pembahasan}

Dari hasil penelitian ditemukan bahwa segregasi sosial pasca Pemilu 2019 di lingkungan SMK Bakti Karya Parigi baik di lingkungan sekolah maupun di lingkungan asrama tidak pernah terjadi, dikarenakan seluruh siswa, guru dan masyarakat setempat cenderung sudah terbiasa dengan perbedaan pendapat dari segi apapun, mereka seolah terbiasa dengan keberagman dan kerukunan yang ada dan seolah tidak peduli dengan panasnya ruang demokrasi negeri yang terjadi pasca pemilu 2019, namun mereka tetap bersinergi dalam upaya memberikan hak pilih mereka dalam pemilu 2019. SMK Bakti Karya Parigi sebagai salah satu pelopor pendidikan multikultural di Indonesia telah memberikan contoh yang baik pada masyarakat untuk dapat saling menghargai dan menghormati perbedaan yang ada sehingga nantinya masyarakat tidak akan mudah terprovokasi dan termanipulasi oleh orang-orang yang ingin memecah belah persatuan dan keutuhan umat. Pendidikan multikultural bagi masyarakat sangatlah penting karena dari pendidikan multikultur tersebut masyarakat akan dapat memahami perbedaan, baik dari segi agama, sosial, dan budaya.

Pendidikan tidaklah dapat dipisahkan pada proses pembelajaran yang berlangsung dalam suatu lembaga pendidikan tertentu. Oleh karena itu pelaksanaan pembelajaran haruslah direncanakan dan dikonsep sedemikian sehingga dalam pelaksanaannya diharapkan berjalan lancar dan sesuai dengan yang diharapkan. Banyak hal yang mendukung proses berlangsung pelaksanaan pembelajaran diantaranya adalah ruang/ kelas, media, sumber belajar, strategi, metode, kemampuan kognitif yang dimiliki guru bahkan kemampuan guru untuk berinteraksi dengan siswa, kurikulum yang diterapkan dan sebagainya.

Kegiatan pembelajaran dan hari aktif belajar di SMK Bakti Karya Parigi sama dengan sekolah umum lainnya. Dari hasil wawancara dengan guru PAI dan Waka Kurikulum yang kaitannya dengan pelaksanaan pembelajaran diperoleh data bahwa:

Jadwal pelajaran pendidikan agama Islam itu dilaksnakan hari senin, rabu dan kamis mulai jam 12.00 sampai jam 15.00. Untuk pembelajaran dilaksanakan dari mulai hari senin sampai dengan hari sabtu. (Wawancara dengan Heri Nurdiansyah, 2019)

Pembelajaran pendidikan agama Islam di SMK Bakti Karya Parigi dilaksanakan pada hari Senin untuk kelas XI, Rabu untuk kelas X dan hari Kamis untuk kelas XII sedangkan waktunya adalah dari pukul 12.00 s/d 15.00 WIB. Pelaksanaan pembelajaran terkadang tidak tepat waktu karena siswanya sebagian ada yang makan, sholat dan terkadang ada siswa yang tidur karena 
kecapean ada kegiatan di kampung nusantara pada hari minggu atau kalau ada tamu dari luar yang dalam jumlah besar pengunjungnya.

Selain pembelajaran pendidikan agama Islam di sekolah juga terdapat pembelajaran pendidikan agama Islam di asrama. Waktu diasrama jauh lebih banyak dibandingkan waktu di sekolah. Oleh karena itu perlu di koordinir sehingga siswa kegiatan yang bermanfaat di asrama. Selain pemberian porsi legih terhadap jiwa entrepreneur pemberian pembelajaran agama Islam pada khususnya juga mendapatkan porsi lebih. Dalam hal ini diperkuat dari hasil wawancara dengan beberapa informan, diantaranya adalah sebagai berikut :

Di SMK Bakti Karya Parigi ini pembelajaran agama Islam bukan hanya diberikan di sekolah saja, tetapi di asrama pun juga diberikan. Bentuk pembelajarannya adalah melalui diadakannya diskusi-diskusi dan juga ibadah sesuai agama masing-masing setiap hari. Misalnya, ketika shubuh yang muslim melaksanakan sholat berjama'ah, dan yang menganut agama lain beribadah (berdoa) bersama-sama sesuai dengan agama masing-masing. (Wawancara dengan Heri Nurdiansyah, 2019).

Asrama yang ada di SMK Bakti Karya Parigi ini berfungsi sebagai tempat tinggal siswa, karena siswa SMK Bakti Karya Parigi ini adalah anak dari berbagai suku dan bangsa yang ada di Indonesia. Maka, dalam hal ini kegiatan asrama masih terintegrasi dengan kegiatan sekolah. Evaluasi dilakukan selama 24 jam, dari bangun tidur sampai tidur lagi. (Wawancara dengan Yuhanah, 2019).

Pembelajaran agama Islam di asrama biasanya dalam bentuk forum diskusi yang membahas permasalahan sehari-hari yang berkaitan dengan agama, kultum yang diadakan setiap kali jamaah subuh yang digilir secara bergantian antara siswa satu dengan siswa lainnya, pemberian materi fiqih yang diberikan langsung oleh guru agama Islam. Hal ini dilakukan untuk mempermudah dalam memantau semua kegiatan dan kehidupan setiap siswa selama 24 jam.

Proses pembelajaran dalam pendidikan agama selalu memperhatikan individu peserta didik serta menghormati harkat, martabat dan kebebasan berpikir mengeluarkan pendapat dan menetapkan pendiriannya, sehingga bagi peserta didik belajar merupakan hal yang menyenangkan dan sekaligus mendorong kepribadiannya berkembang secara optimal, sedangkan bagi guru, proses pembelajaran merupakan kewajiban yang bernilai ibadah, yang harus dipertanggung jawabkan.

Pelaksanaan pembelajaran pendidikan agama Islam berwawasan multikultural di SMK Bakti Karya Parigi lebih mengedepankan pada pendekatan sosiologis, pendekatan sosiologis merupakan pendekatan yang lebih mengedapankan pada hubungan antara manusia dengan manusia lainnya yang hidup bersama satu sama lainnya. Latar belakang siswa yang berbeda dari segi kehidupan, tradisi, sehingga menjadikan pola pikir siswa satu sama lainnya berbeda sekalipun sama-sama satu agama Islam. Langkahlangkah pembelajaran pendidikan agama Islam dikelompokkan sebagai berikut: 
Strategi pembelajaran memegang peran penting untuk menunjang berlangsung proses pembelajaran. Penerapan strategi biasanya beriringan dengan penerapan metode dalam pembelajaran. Dalam hal ini hasil wawancara dengan guru PAI adalah sebagai berikut :

Strategi pembelajaran antara lain active learning, quantum learning jarang tapi masih saya gunakan quantum learning, yang banyak active learning. (Wawancara dengan Mulyadi, 2019).

Dalam pembelajaran pendidikan agama Islam menanamkan nilai-nilai karakter dan nilai-nilai multikultural. Salah satu diantaranya adalah kebersamaan dan menghargai perbedaan, SMK Bakti Karya Parigi merupakan sekolah yang memiliki latar belakang dan kultur yang berbeda-beda dari berbagai daerah diseluruh Indonesia sehingga perlu adanya suatu nilai yang mempersatukan mereka. Dalam pelaksanaan pembelajaran pendidikan agama Islam tidak semua nilai-nilai yang direncanakan dalam perencanaan teraplikasikan semua di pelaksanaan pembelajaran, yang lebih diutamakan adalah nilai-nilai kebersamaan misalnya toleransi, hidup bersama, saling menghargai, tolong menolong. Dari hasil wawancara dapat disimpulkan sebagai berikut :

Nilai pray together, terus kepahaman tentang sekte mereka. Adalah hal yang sering saya ambil untuk bagaimana mereka tetap saling toleransi (tasamuh) walau mereka berbeda agama, yang seagama tetap berbeda aliran Muhammadiyah dan NU tapi mereka tetap bersama (together). (Wawancara dengan Mulyadi, 2019).

Toleransi adalah bagaimana kita membina kerukunan antar manusia itu ya, memang sejak diciptakan Tuhan, kita itu kan sudah berbeda lah bagaimana perbedaan itu menjadi suatu bentuk kerukunan. Karena saya yakin Tuhan menciptakan perbedaan itu bukan untuk bertengkar, berbenturan dsb tapi itu adalah mungkin salah satu tujuan bagaimana dengan perbedaan ini supaya kita bisa merekatkan diri. Walaupun pada akhirnya ada orang yang memenej perbedaan itu menjadi suatu pertengkaran. Tapi disini tidak, dengan perbedaan itu kita bisa melakukan toleransi, teman yang seperti itu bagaimana kalau kita bisa membantu. Kita tarik benang merahnya itu yang universal misalnya saling menghormati, saling memberi itu kan sesuatu yang disemua agama ada, jadi kita tidak sampai menjurus ke aqidah-aqidah. (Wawancara dengan Irpan Ilmi, 2019).

Saling menghargai, wujudnya misalnya perayaan agama itu tidak boleh anak-anak lain yang non agama merayakan itu tidak bantu, jadi semuanya itu harus ikut bantu dan ikut andil. Misalnya pertunjukkan, di Islam ada pertunjukan kaya Idul Adha mereka menampilkan parodi itu anak-anak non Islam harus tetap berkerudung, jadi tidak ada tendensi nanti berkerudung disangkanya Islam. Walaupun agama Kristen mereka tetap saja berkerudung. Karena disini ditanamkan kalau kamu mau beribadah konsisten pada agamamu ya kamu sendiri, sholat itu kita tidak boleh ganggu dari agama lain. (Wawancara dengan Heri Nurdiansyah, 2019).

Dengan adanya kesadaran akan adanya banyak perbedaan para siswa tidaklah terjadi perpecahan dengan siswa lain baik yang berbeda aqidah yang sesama Islam, bahkan sesama siswa yang beda agama, suku dan sebagainya. Mereka menyadari dalam perbedaan terdapat persamaan yaitu sama-sama anak bangsa Indonesia, sama-sama tinggal dalam satu atap SMK Bakti Karya 
Parigi, berasal dari berbagai daerah dengan latar belakang keluarga kurang mampu, yatim ataupun yatim piatu dan tentunya masih banyak persamaan diantara para siswa SMK Bakti Karya Parigi. Sehingga dalam pelaksanaan pembelajaran pendidikan agama berwawasan multikultural di SMK Bakti Karya Parigi berjalan lancar dan baik.

Pada dasarnya segala macam perbedaan baik dari segi perbedaan agama, suku, ras dan golongan bahkan keyakinan akan paham yang siswa anut tidaklah menjadikan suatu masalah, karena mereka lebih meyakini bahwa mereka semua ada di SMK Bakti Karya Parigi adalah karena berawal dari perbedaan-perbedaan tersebut sehingga mereka semua bisa terpilih menjadi siswa SMK Bakti Karya Parigi. Dengan segala perbedaan yang ada tersebut menjadikan mereka bersatu untuk mewujudkan tujuan cita-cita bangsa Indonesia. Hal ini sesuai dengan Bhineka Tunggal Ika, yang berarti walaupun berbeda-beda tapi tetap satu tujuan. Hal ini diperkuat dari beberapa hasil wawancara sebagai berikut :

Bagian terpenting dari sekolah ini diantaranya adalah multikultur. Perbedaan itu tetap ada tapi perbedaan itu merupakan perekat dari seluruh yang ada disini sehingga itu bisa menjadi jalan untuk memperlancar bagaimana kita bertoleransi. (Wawancara dengan Ilmi, 2019).

Tidak ada perpecahan, jadi anak-anak diajari untuk lebih menghargai lima agama tersebut. Disitu diharapkan siswa mengetahui kalau memang di Indonesia itu beragam. Tapi karena sudah kita sepakati melaksanakan suatu kerukunan dalam suatu keberbedaan maka kita itu sudah siap kalau misalnya nanti ada sesuatu yang menjadi semacam kendala bagaimana kita mengatasinya dengan bijaksana. (Wawancara dengan Heri Nurdiansyah, 2019).

Dengan adanya perbedaan dan keberagaman ras, agama, suku, golongan bahkan paham justru dianggap sebagai sarana untuk memperluas pengetahuan dan mempererat tali persaudaraan di antara sesama siswa baik yang seagama maupun dengan siswa yang berbeda agama. Dengan dasar keragaman agama, suku, ras menjadikan sesama siswa semakin kompak dan kebersamaan, hal ini ditunjukkan dengan berbagai kegiatan dan pertunjukkan yang seringkali menjadi daya tarik tersendiri bagi para tamu dan pengunjung khususnya di Kampung Nusantara Desa Cintakarya Kecamatan Parigi Kabupaten Pangandaran.

Cara bijaksana dalam mengatasi segala macam perbedaan yang ada diantaranya dengan menempatkan semua siswa dalam satu asrama tanpa memandang suatu agama apapun, perlakuan yang sama terhadap semua siswa, merayakan perayaan hari-hari besar dari lima agama tersebut (Islam, Protestan, Katholik, Hindu dan Budha), melibatkan siswa yang beragama lain dan yang berpaham lain dalam suatu perayaan hari-hari besar agama dan sebagainya.

Metode pembelajaran dalam pelaksanaan pembelajaran pendidikan agama Islam sangat menunjang keberhasilan tujuan pembelajaran. 
Pembelajaran di SMK Bakti Karya Parigi merupakan multi pembelajaran yang tidak monoton pembelajaran di dalam kelas saja, namun lebih di arahkan untuk pembelajaran di luar kelas sehingga metode yang digunakan disesuaikan dengan tempat pembelajaran. Hal ini diharapkan siswa dapat lebih memahami dan mengurangi kebosanan terhadap mata pelajaran PAI yang dianggap mata pelajaran membosankan di sekolah-sekolah pada umumnya karena dari tahun ke tahun materinya hampir sama dan identik dengan cerita. Metode yang digunakan berdasarkan hasil wawancara dengan guru PAI adalah sebagai berikut:

Di sini biasanya membahas yang kaitannya dengan iman, karena disini tempatnya bagus bisa melihat pemandangan alam di sekitar sekolah yang indah, dan cukup berdekatan dengan tempat pemakaman, bahkan saya tidak segan mengajak mereka untuk kesana. Dengan hal tersebut anak akan dapat menanami alam dan isinya sebagai ciptahan Allah SWT. (Wawancara dengan Mulyadi, 2019).

Metode pembelajaran yang digunakan adalah metode ceramah, inquiry, information search, dan team work. Dan selama dua minggu kemarin itu menggunakan metode observasi, team work sama information search, yang diajari lingkungan sekitar sama keadaan yang ada di Kampung Nusantara dan lingkungan sekitar sekolah. Tapi untuk keseluruhannya yang sering jelas ceramah, inquiry, learning communication sama yang terakhir yang jelas penugasan itu yang sering saya gunakan. (Wawancara dengan Mulyadi, 2019).

Meskipun sebenarnya materi mata pelajaran PAI identik dengan cerita namun penyampaian materi dan metode yang diterapkan di sini tidak monoton dengan ceramah. Biasanya guru hanya memberikan sedikit pengantar untuk mengawali pembelajaran yang kemudian di lanjutkan para siswa untuk membahas dan mendiskusikan materi yang telah disiapkan guru. Guru berfungsi sebagai pengarah dan tidak mendominasi pembelajaran. Beberapa metode yang diterapkan dalam pembelajaran PAI adalah dengan mempraktekkan langsung atau dengan pengamatan langsung ke materi pembelajaran. Dari hasil wawancara diperoleh data sebagai berikut :

Ini babnya bab sembilan masalah perilaku terpuji, babnya adab berpakaian dan berhias, adab dalam perjalanan dan adab bertamu dan menerima tamu. Untuk bertamu dan menerima tamunya anak-anak bertugas pada hari Minggu bagaimana mereka mengecek tamu yang datang sama teman-teman yang jadi tuan rumah. Kan mesti ada tamu disini. (Wawancara dengan Mulyadi, 2019).

Kegiatan siswa SMK Bakti Karya Parigi pada hari Minggu adalah pembiasaan, maksudnya disini adalah mempraktekan ilmu yang diperolehnya selama pembelajaran di sekolah pada hari Senin sampai dengan Sabtu. Penerapan metode dalam pembelajaran PAI terlaksana dengan baik, namun dalam pembelajaran PAI terkadang mengalami kendala atau hambatan yang kaitannya dengan waktu pembelajaran. Hal ini menjadikan metode dan konsep yang telah dipersiapkan tertunda karena suatu hal. 
Dalam pemberian materi pendidikan agama Islam di SMK Bakti Karya Parigidisesuaikan dengan Kurikulum 2013 sama seperti sekolah umum lainnya. Hal ini diperkuat dengan hasil wawancara sebagai berikut :

Kalau menurut silabus dari Kementrian Agama saya pikir guru agama sudah mengerti, Disini bagaimana setiap kali mengajarkannya tetap berpegang pada visi, misi sekolah ini. Diantaranya adalah kita itu berbeda, dan kalau mungkin bisa saya sampaikan ya bagaimana perbedaan ini tetap bisa dikelola dengan yang berbeda karena ciri sekolah atau keunikan sekolah ini adalah perbedaan ini. (Wawancara dengan Heri Nurdiansyah, 2019).

Materi pelajaran disesuaikan dengan misi SMK Bakti Karya Parigi diantaranya menyelenggarakan pembelajaran bidang keimanan dan ketakwaan (IMTAK), dan pengembangan ilmu pengetahuan dan teknologi (IPTEK) yang dalam penyampaiannya tidak boleh memihak dan bermadzab tertentu, materi yang disampaikan bersifat global sesuai dengan keyakinan dan paham yang dianut siswa masing-masing, tidak menekankan adanya perbedaan dalam paham tertentu di dalam agama Islam, namun lebih menanamkan adanya keanekaragaman paham dan tata cara dalam pelaksanaan ibadah adalah sesuatu yang patut dipelihara untuk tetap menciptakan keharmonisan dan kerukunan khususnya di lingkungan SMK Bakti Karya Parigi. Dalam penyampaian materi biasanya guru memberikan sebuah pengantar yang berkaitan dengan materi, kemudian siswa diberi kesempatan menjelaskan atau memaparkan dari sudut pandang dan pengetahuan siswa tentang materi tersebut.

Dengan latarbelakang kehidupan, budaya dan juga teradisi yang berbeda dari masing-masing siswa maka pendapat dan sudut pandang siswa satu dengan yang lainnya juga berbeda. Dari sini tidak hanya memandang suatu organisasi tertentu misalnya Muhammadiyyah ataupun NU ataupun lainnya. Disini tidak berbicara tentang benar atau salah namun lebih diarahkan pada perbedaan latarbelakang kehidupan, budaya dan juga teradisi yang berbeda dari siswa yang berasal dari berbagai pulau tersebut. Secara tidak langsung hal ini menambah keilmuan mereka tentang tradisi Islam dari berbagai pulau yang belum tentu terjadi di pulau lainnya.

Materi yang disampaikan guru PAI tetap mengacu ke panduan materi yang berlaku dari Kementrian Agama, sekalipun dalam pelaksanaannya terdapat perbedaan pandangan dan paham tentang aqidah, pelaksanaan ibadah dari beberapa siswa guru membenarkan dan tidak menyalahkan tentang faham yang dianut beberapa siswa. Perbedaan yang ada dianggap sebagai bagian dari khilaf ulama yang wajar terjadi karena banyaknya golongan dalam Islam sendiri. Namun yang lebih sering diajarkan adalah yang bersifat nasional bukan memihak salah satu paham. Beberapa perbedaanperbedaan yang sering terjadi di antara beberapa siswa berdasarkan hasil wawancara adalah sebagai berikut: 
Dalam hal ibadah ada yang subuh pakai qunut ada yang tidak. Ada yang puasa sunah ada yang tidak, seperti Rajab itu tidak wajib bahkan ada yang ngomong dhaif. Sholat semua sama kecuali qunut, sholat tarawih ada yang 20 ada 114. Ibadah lainnya, ada yang sholawat nabi ada yang mau ikut ada yang tidak mau. (Wawancara dengan Mulyadi, 2019).

Media dalam pembelajaran

Faktor penunjang lain untuk menunjang keberhasilan pembelajaran adalah penggunaan media pembelajaran. Dalam kaitannya dengan media pembelajaran yang di gunakan dalam pembelajaran PAI di SMK Bakti Karya Parigi berdasarkan hasil wawancara adalah sebagai berikut :

Alam adalah media yang pertama dan utama. Untuk media elektroniknya laptop terkadang menggunakan LCD. Jika saya tidak keluar ke alam, tidak tadabur alam, tidak perlu observasi berarti saya menggunakan LCD. Jika LCD tidak saya gunakan berarti saya menggunakan alam sebagai rujukan media. Buku yang jelas, al-Qur'an terus terjemah, LCD, laptop serta alam sekitar mulai dari SPI sampai tempat tujuan. (Wawancara dengan Mulyadi, 2019).

Tempat berlangsungnya pembelajaran

Pembelajaran di SMK Bakti Karya Parigi berbeda dengan sekolah lain pada umumnya, pembelajaran di SMK Bakti Karya Parigi lebih identik natural class, lain halnya dengan sekolah umum lainnya yang lebih banyak mengadakan pembelajaran di dalam kelas ataupun laboratorium. Hal ini diperkuat dari beberapa pernyataan hasil wawancara, hasilnya adalah sebagai berikut :

Pembelajaran menerapkan sistem natural class. Jadi kelas tidak harus di dalam kelas atau building class. Memang disini ada natural class dan ada building class, memang disini karena tanahnya luas maka disini juga menggunakan kelas-kelas natural seperti didepan ini, joglo, outdoor jadi pada dasarnya disini lebih fleksibel. Mungkin nanti kalau memerlukan tempat yang administratif biasannya ada di dalam kelas. (Wawancara dengan Mulyadi, 2019).

Pembelajaran pendidikan agama Islam di dalam ruang kelas sebisa mungkin diminimalisir karena biasanya lebih menjadikan siswa cepat bosan, jenuh bahkan terkadang mengantuk. Namun pembelajaran di dalam kelas tetap saja dilaksanakan dan biasanya pada materi-materi tertentu yang menggunakan media seperti laptop dan LCD, ataupun alat peraga lainnya yang sekiranya membutuhkan ruangan. Terkadang kelas hanya digunakan untuk pelaksanaan ujian baik ujian tulis dan lisan. Pada dasarnya pembelajaran dilaksanakan di berbagai ruangan namun bukan ruang kelas yang dimaksudkan. Lokasi dan tempat pembelajaran disesuaikan dengan materi dan metode yang digunakan. Berhubung metode ceramah relatif dikesampingkan maka tempat pembelajaranpun lebih identik diarahkan diluar kelas. Dengan adanya variasi tempat pembelajaran yang berpindah tempat diharapkan dapat menunjang tersampainya materi dan semangat para siswa untuk berperan aktif dan paham dalam pembelajaran. 
Tempat pembelajaran pendidikan agama Islam disesuaikan dengan materi yang akan dibahas. Sebagai contoh (1) pembelajaran di dalam kelas kelas biasanya untuk membahas materi yang berkaitan dengan qur'an hadist, sejarah, aqidah, ibadah. (2) di bawah pohon mangga biasanya untuk membahas materi yang berkaidah dengan tarikh/ sejarah islam, fiqih yang lebih identik dengan hal halal haram, aqidah. (3) lingkungan sekolah biasanya untuk membahas tentang materi aqidah dan tentang lingkungan. (4) Kampung Nusantara biasanya untuk membahas materi tentang muamalah, akhhlah, perekonomian atau usaha. (5) sungai biasanya untuk membahas tentang kerusakan lingkungan akibat ulah manusia seperti tanah longsor, limbah atau pencemaran air; (6) kubura atau tempat pemakaman biasanya untuk membahas materi tentang keimanan, hari pembalasan, kehidupan setelah mati. (7) asrama biasanya untuk membahas materi tentang ibadah, keimanan, Qur'an, akhlak, fiqih, tarikh.

Perbedaan paham dalam Islam di SMK Bakti Karya Parigi terlihat, hal ini bisa diketahui terutama dari segi bagaimana cara beribadahnya siswa dalam kehidupan sehari. Hal ini terjadi karena latarbelakang kehidupan yang berbeda antar siswa satu dengan siswa lain sebelum memasuki SMK Bakti Karya Parigi.

Salah satu dampak penanaman nilai-nilai multikultural di SMK Bakti Karya Parigi antara lain adanya kerukunan dan kebersamaan antar siswa yang lintas atau berbeda agama (Islam, Protestan, Katholik, Hindu dan Budha), lintas kultural (Jawa, Kalimanta, Irian Jaya, Sumatra, Sulawesi, Papu dan sebagainya), lintas suku bangsa (suku Jawa, suku Kalimanta, suku Irian Jaya, suku Sumatra, suku Sulawesi dan sebagainya).

Pemberian nilai-nilai multikultural di SMK Bakti Karya Parigi memberikan dampak positif bagi kehidupan siswa dalam kehidupan seharihari mereka. Beberapa dampaknya dari hasil wawancara adalah sebagai berikut: (1) Mereka bisa menerapkan dalam kehidupan sehari-hari dalam kebersamaan, contoh mereka bisa menyapa, senyum, salam kepada tamutamu kampoeng kidz baik mererka kenal dan tidak kenal. Itu sudah diakui oleh beberapa mahasiswa bahkan doctor yang sudah ke Kampung Nusantara. (2) Mereka beribadah bersama-sama dalam waktu yang sama di tempat, lantai dengan di tempat lantai yang berbeda tapi dalam gedung yang sama tidak membedakan itu Islam dan Kristen. (3) Mereka saling peduli (care) satu sama lain, baik siswa sama siswa, siswa sama guru, siswa sama karyawan. Caranya disini dengan simpatinya tinggi, baik itu sakit, bahagia semua mereka tunjukan melalui didikan nilai-nilai yang kita berikan. Sengaja yayasan tidak membuat tempat ibadah supaya mereka punya inisiatif untuk membuat semua alam sekitar menjadi sebuah tempat ibadah tapi tetap disediakan mushola untuk Islam. (Wawancara dengan Mulyadi, 2019). 
Dampak lainnya dari penanaman nilai-nilai multikultural di SMK Bakti Karya Parigi selain kebersamaan antara lain adalah adanya sikap saling peduli yang tinggi satu sama lain diantara siswa, dalam hal hubungan sesama manusia yaitu adanya kerukunan antar siswa baik yang seagama maupun yang berbeda agama. Dalam hal ini diperkuat dengan pernyataan kepala sekolah dalam wawancara, hasilnya sebagai berikut :

Memperluas hubungan antar sesama manusia (habblum minannas), kemudian hubungan antara manusia dengan Allah (hablum minallah) itu kan masing-masing sesuai dengan agama masing-masing, yang intinya justru kita malah banyak yang ke hubungan antar sesama manusia (hablum minannas). Walaupun kita sangat menghargai hubungan antara manusia dengan Allah (hablum minalla). (Wawancara dengan Irpan Ilmi, 2019)

Kegiatan keagamaan yang bernuansa multikultur dalam pembelajaran PAI seringkali di laksanakan di SMK Bakti Karya Parigi, bukan hanya di ikuti siswa yang beragama Islam saja namun juga seringkali di ikuti oleh siswa dari agama lain. Hal ini terjadi karena sedikitnya jumlah siswa yang beragama Islam inilah yang membedakan dengan sekolah umum lainnya.

Kegiatan keagamaan yang bernuansa multikultur dalam pembelajaran PAI seringkali di laksanakan di SMK Bakti Karya Parigi, bukan hanya di ikuti siswa yang beragama Islam saja namun juga seringkali di ikuti oleh siswa dari agama lain. Hal ini terjadi karena sedikitnya jumlah siswa yang beragama Islam inilah yang membedakan dengan sekolah umum lainnya. Beberapa kegiatan keagamaan dari hasil wawancara adalah sebagai berikut:

Untuk perayaan keagamaan itu tetap melaksanakan, jadi sekolah kita itu paling banyak merayakan hari raya besar karena kita ada lima agama. Sekolah itu mengijinkan, kalau memang itu waktunya hari besar agama itu yang ada di sekolah ini y kita rayakan. Modelnya kita serahkan kepada pengurus OSIS (Organisasi Siswa Intra Sekolah) Maulid Nabi, Idul Adha hari raya Idul Fitri tetap dirayakan, Tarawih juga tetap dilaksanakan. (Wawancara dengan Irpan Ilmi, 2019).

Memang disekolah memfasilitasi, itu konsekuensi dari lima agama itu karena perayaan agama adalah salah satu daripada bagaimana anak-anak itu menerapkan teladanteladan para aulia. Itu kan bagian dari mereka mencontoh. Secara ritual mereka sendirisendiri, hanya kalau perayaan itu seperti halnya membuatkan dekornya saya pikir itu kan bukan pencampuran. Selain itu ini kalau pas ada acara-acara peringatan hari besar agama tertentu, semua siswa kami libatkan sebagai panitia. Selain karena kurangnya personil, juga untuk melatih siswa agar mampu hidup rukun meskipun berbeda-beda. Ya seperti semboyan negara kita lah, Bhineka Tunggal Ika, berbeda-beda tetapi tetap bersatu juga. (Wawancara dengan Heri Herdiansyah, 2019).

Dari hasil wawancara tersebut didapat keterangan bahwa baik kepala sekolah, waka kurikulum, guru agama Islam maupun guru mata pelajaran lainnya dan juga siswa di SMK Bakti Karya Parigi selalu merespon positif dengan mendukung pelaksanaan perayaan hari besar lima agama (Idul Fitri, Idul Adha, Natal, Paskah, Kenaikan Isa Al-Masih, Nyepi dsb) yang melibatkan semua siswa walaupun berbeda agama sebagai panitia. Selain itu siswa SMK Bakti Karya Parigi juga antusias dengan dilibatkannya mereka sebagai panitia. 
Peran sekolah dalam memfasilitasi peringatan hari besar agama Islam di SMK Bakti Karya Parigi antara lain dengan mendatangkan Kyai atau ustad sebagai penceramah dalam suatu acara Isra Mikraj, Maulid Nabi pengadaan kurban di hari raya Idul Adha, pengadaan sholat tarawih di bulan suci Ramadhan dan pembayaran zakat fitrah di akhir Bulan Ramadhan. Semuanya itu tidak lepas dari peran dan dukungan serta kerjasama siswa dengan sekolah.

\section{Kesimpulan}

Segregasi Sosial Pasca Pemilu 2019 di lingkungan SMK Bakti Karya Parigi baik di lingkungan sekolah maupun di lingkungan asrama tidak pernah terjadi. Mereka seolah terbiasa dengan keberagman dan kerukunan yang ada dan seolah tidak peduli dengan panasnya ruang demokrasi negeri yang terjadi pasca pemilu 2019 dan tetap memberikan hak pilih mereka dalam pemilu 2019. Pendidikan multikultural bagi masyarakat sangatlah penting karena dari pendidikan multikultur tersebut masyarakat akan dapat memahami perbedaan, baik dari segi agama, sosial, dan budaya.

\section{DAFTAR PUSTAKA}

Ahmadi Rulam, (2005). Memahami Metodologi Penelitian Kualitatif, Malang :

UIN Malang-Press

Bisariyadi, et.al., 2012. Komparasi Mekanisme Penyelesaian Sengketa Pemilu di

Beberapa Negara Penganut Paham Demokrasi Konstitusional. Jurnal

Konstitusi Volume 9, Nomor 3, September 2012

Hasan Iqbal, (2004). Analisis Penelitian dengan Statistik, Jakarta : Bumi

Aksara

Moleong J Lexy, (2006). Metodologi Penelitian Kualitatif. Bandung : PT

Remaja Rosdakarya

Nurtjahjo, Hendra. 2006. Filsafat Demokrasi. Jakarta: Bumi Aksara.

Sugiyono, (2005). Memahami Penelitian Kualitatif, Bandung : CV Alfabeta

Suharsimi Arikunto, (2006). Prosedur Penelitian Suatu Pendekatan Praktik, (cetakan ke-13). Jakarta : PT Rineka Cipta 
